\title{
STUDY OF THE LIVER METABOLIC ACTIVATION OF SOME PLANT PHENOLIC COMPOUNDS
}

\author{
Iliya Zhelev ${ }^{1}$, Yana Koleva ${ }^{2}$, Ivanka Dimitrova-Dyulgerova ${ }^{3}$, Svetlana Georgieva ${ }^{1}$ \\ ${ }^{1}$ Department of Pharmaceutical sciences, Faculty of Pharmacy, Medical University of \\ Varna, ${ }^{2}$ Department of Organic Chemistry, Faculty of Natural Sciences, \\ University „Prof. Assen Zlatarov”- Burgas, 'Department of Botany, Faculty of Biology, \\ Plovdiv University "Paisii Hilendarski"- Plovdiv
}

\begin{abstract}
Phenolic compounds form one of the main classes of secondary metabolites. The widespread use of flavonoids and phenolic acids necessitates the study of their metabolism. The aim of this work is to predict the possible metabolites of some plant phenolic compounds by a specialized software (OECD (Q)SAR Application Toolbox. Analysis of data reveals that after metabolic activation in liver (observed pathways) for five of the six plant phenolic compounds liver metabolism was not observed. Only for one compound (Luteolin) metabolic activation in liver (observed pathways) was observed.
\end{abstract}

Keywords: phenolic compounds, flavonoids, phenolic acids, Quantitative Structure-Activity Relationships

\section{INTRODUCTION}

Phenolics are compounds possessing one or more aromatic rings with one or more hydroxyl groups. They are broadly distributed in the plant kingdom and are the most abundant secondary metabolites of plants, with more than 8,000 phenolic structures currently known. Despite their wide distribution, the health effects of polyphenols have come to the attention of nutritionists in recent years. The preventive effects of these plant metabolites in terms of cardiovascular, neurodegenerative diseases and cancer are deduced from epidemiologic data as

\footnotetext{
Address for correspondence:

Svetlana Georgieva, PhD

Dept. of Pharmaceutical sciences

Faculty of Pharmacy

Medical University of Varna

55 Marin Drinov Str., 9002 Varna, Bulgaria

e-mail:fotkova@abv.bg
}

Received: February 19, 2014

Accepted: April 3, 2014 well as in vitro and in vivo $(1,3,6,9,19)$. Among these compounds flavonoids and phenolic acids constitute one of the most ubiquitous groups of all plant phenolics.

Flavonoids are constituents of fruits, vegetables, plant-derived beverages as tea and wine, as well as components present in dietary supplements. Over 4000 different naturally occurring flavonoids have been described (11). Phenolic acids (hydroxycinnamica and hydroxvbenzoic acids) belong to the group of phenolic compounds as well, and occur in fruits as esters glycosideas and amides. The most common hydroxycinnamic acids are p-coumaric, caffeic and ferulic acid, while the corresponding hydroxybenzoic acids are p-hydroxybenzoic, gallic, ellagic, 3,4-dihydroxybenzoic, vanillic, and syringic acid (5).

However, the potential toxicity of these two types of phenolic components has not been well studied (7).

In the recent years methods for structural features and properties of a molecule and its impact on biological activity were investigated. One of them 
Iliya Zhelev, Yana Koleva, Ivanka Dimitrova-Dyulgerova et al.

is Quantitative Structure-Activity Relationship (QSAR) - a method of studying a series of molecules of different structures with varying observed properties and attempting to find empirical relationships between structure and property or activity. QSAR has been widely used for new drug discovery pro-
The aim of this work is to predict the possible metabolites of some plant phenolic compounds by a specialized software OECD - (Q)SAR Application Toolbox. Analysis of data reveals that after metabolic activation in liver (observed pathways) for five of the six plant phenolic compounds liver metabolism

Table 1. CAS number, name and structure of some phenolic compounds

№ CAS number Name of compound Structure of compound

$1 \quad 327-97-9$

$2 \quad 530-59-6$

$3 \quad 1135-24-6$

Ferulic acid

4

491-70-3

Luteolin

5

$520-18-3$

Kaemferol

Myricetin<smiles>O=C(O)C1(O)C[C@H](O)[C@H](O)[C@@H](O)/C(=C/C=C/c2ccc(O)c(O)c2)O1</smiles><smiles>COc1cc(/C=C/C(=O)O)cc(OC)c1O</smiles><smiles>COc1cc(/C=C/C(=O)O)ccc1O</smiles><smiles>O=c1cc(-c2ccc(O)c(O)c2)oc2cc(O)cc(O)c12</smiles><smiles>O=c1c(O)c(-c2ccc(O)cc2)oc2cc(O)cc(O)c12</smiles><smiles>O=c1c(O)c(-c2cc(O)c(O)c(O)c2)oc2cc(O)cc(O)c12</smiles>

cesses, but also for the prediction of metabolism and was not observed. Only for one compound (Luteotoxicity of chemical structures (14). 
lin) metabolic activation in liver (observed pathways) was observed.

\section{MATERIAL AND METHODS}

Compounds. Some investigated phenolic compounds (2) are presented in Table 1.

OECD (Q)SAR Application Toolbox. (Quantitative) Structure-Activity Relationships [(Q)
SARs] are methods for estimating the properties of a chemical from its molecular structure and have the potential to provide information on the hazards of chemicals, while reducing time, monetary costs and animal testing currently needed. To facilitate practical application of $(\mathrm{Q}) \mathrm{SAR}$ approaches in regulatory contexts by governments and industry and to improve their regulatory acceptance, the

Table 2. Probable metabolic activation of some plant phenolic compounds by (Q)SAR Application Toolbox

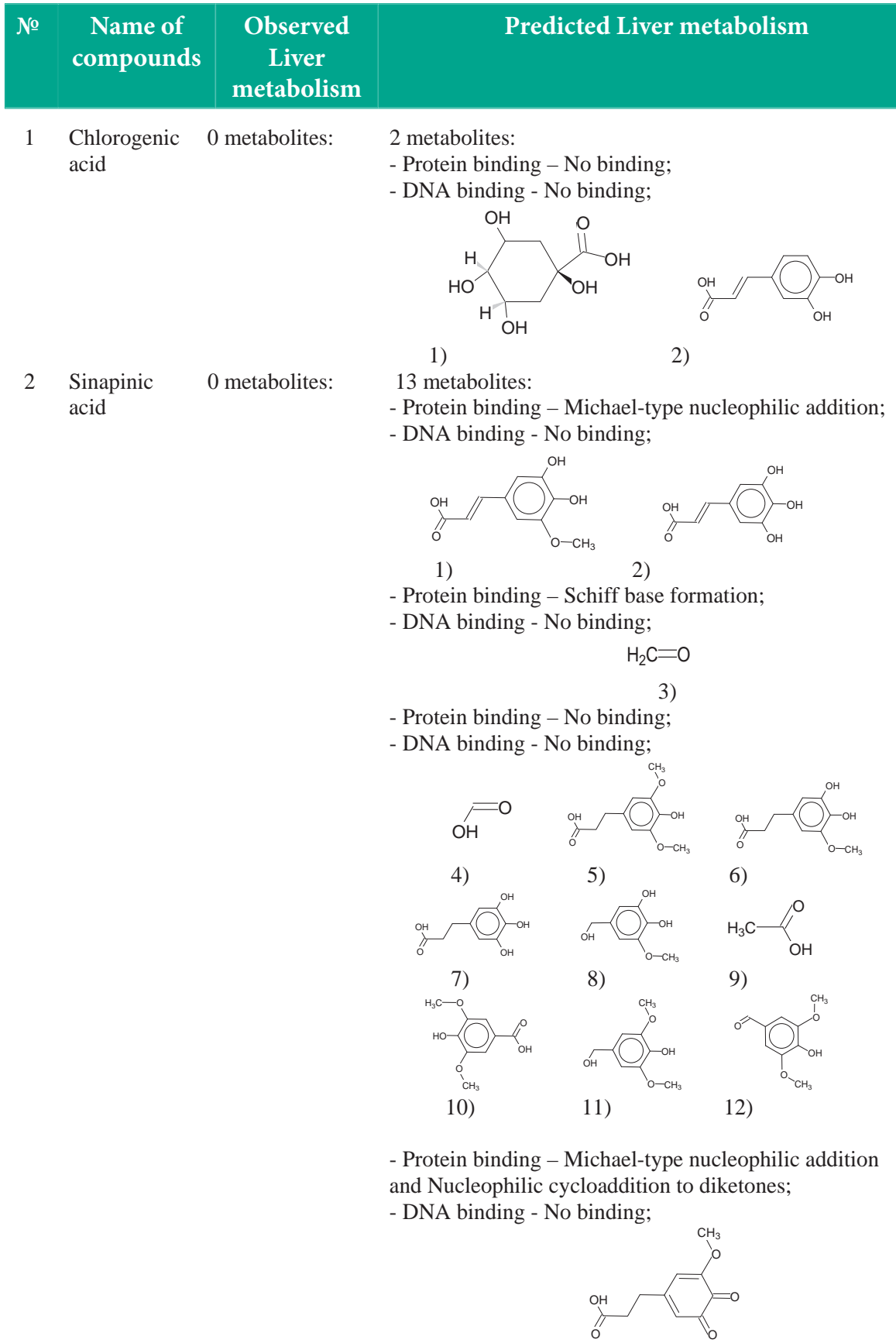

13) 
3 Ferulic acid 0 metabolites:

11 metabolites:

- Protein binding - Michael-type nucleophilic addition; - DNA binding - No binding;

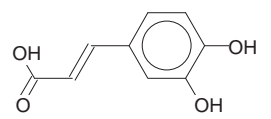

1)

- Protein binding - Schiff base formation; - DNA binding - No binding;

$$
\mathrm{H}_{2} \mathrm{C}=\mathrm{O}
$$

2)

- Protein binding - No binding; - DNA binding - No binding;

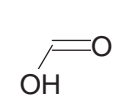

3)<smiles>OCc1ccc(O)c(O)c1</smiles>

6)

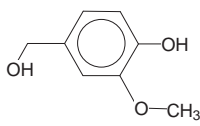

9)

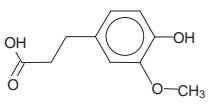

4)

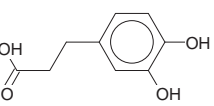

5)

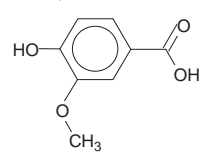

8)

- Protein binding - Michael-type nucleophilic addition and Nucleophilic cycloaddition to diketones;

- DNA binding - No binding;<smiles>O=C(O)CCC1=CC(=O)C(=O)C=C1</smiles>

11)

4 Luteolin 3 metabolites:

- Protein binding - Michael-type

nucleophilic addition;

- DNA binding - No binding;
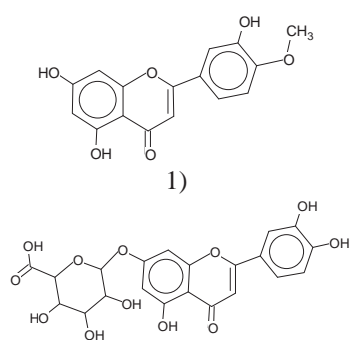

2)

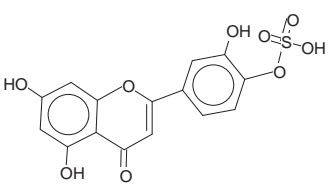

3) 
Study of the liver metabolic activation of some plant phenolic compounds

5 Kaemfero

6 Myricetin
0 metabolites:

0 metabolites:

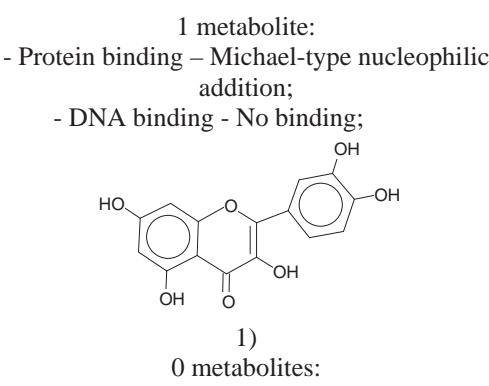

to proteins, RNA, and to endogenous substances of lower molecular weight such as glutathione (12). The complexity of the reaction of electrophilic metabolites with the various nucleophilic sites within cells and the reasons why different electrophilic reagents react at different sites have been interpreted on the basis of the concepts of hard and soft electro philes/ nucleophiles (hard and soft acids/bases) $(13,16,17)$.

Analysis of data in Table 2 reveals that after metabolic activation in liver (observed pathways) for five of the six plant phenolic compounds by $(\mathrm{Q}) \mathrm{SAR}$ Application Toolbox liver metabolism was not observed. Only for one compound (Luteolin) of the six metabolic activation in liver (observed pathways) was observed. The Luteolin has three observed metabolites and 0 predicted metabolites in the liver. The observed metabolites have no DNA binding but some of these metabolites have protein binding. The possible mechanism of protein binding for the observed metabolites is Michael-type nucleophilic addition.

One (Myricetin) of the six phenolic compounds was not metabolically activated in liver. The Chlorogenic acid was metabolically activated in liver (observed and predicted metabolism) but its two predicted metabolites were not active - no protein binding.

Kaemferol is a phenolic compound which has one predicted metabolite. The possible mechanism of protein binding for the predicted metabolite is $\mathrm{Mi}$ chael-type nucleophilic addition. The Sinapinic acid has thirteen predicted metabolites. Predicted metabolites have no DNA binding but some of these metabolites have protein binding. Possible mechanisms of protein binding for the observed metabolites are $\mathrm{Mi}$ chael-type nucleophilic addition, Schiff base formation and Nucleophilic cycloaddition to diketones. Ferulic acid has eleven predicted metabolites. The predicted metabolites have no DNA binding but some 
Iliya Zhelev, Yana Koleva, Ivanka Dimitrova-Dyulgerova et al.

of these metabolites have protein binding. Probable mechanisms of protein binding of the predicted metabolite for Ferulic acid are Michael-type nucleophilic addition, Schiff base formation and Nucleophilic cycloaddition to diketones.

\section{CONCLUSION}

Plant phenols play an important role in human health. There is numerous data on the beneficial effects during their application. All this requires an assessment of potential adverse effects on hepatic metabolism and the ability to induce liver injury.

\section{REFERENCES}

1. Arts IC, Hollman PC. Polyphenols and disease risk in epidemiologic studies. Am J Clin Nutr. 2005;81(1):317-25.

2. ChemIDPlus. A Toxnet Database [Internet]. Available from: http://chem.sis.nlm.nih.gov/ chemidplus

3. Cole GM, Lim GP, Yang F, Teter B, Begum A, $\mathrm{Ma} \mathrm{Q}$, et al. Prevention of Alzheimer's disease: Omega-3 fatty acid and phenolic anti-oxidant interventions. Neurobiol Aging. 2005;26(1):133-6.

4. Jang S, Kelley KW, Johnson RW. Luteolin reduces IL-6 production in microglia by inhibiting JNK phosphorylation and activation of AP-1. Proc Natl Acad Sci. 2008; 105(21):7534-9.

5. Jakobek L, Seruga M, Novak I, MedvidovicKosanovic M. Flavonoids phenolic acids and antioxidant activity of some red fruits. Deut Lebensm Rundsch. 2007;10:369-78.

6. Herteg MG, Feskens EJ, Hollman PC, Katan MB, Kromhout D. Dietary flavonoids and cancer risk in the Zutphen Elderly Study. Nutr Cancer. 1994;22:175-84.

7. Galati G, O'Brien PJ. Potential toxicity of flavonoids and other dietary phenolics: significance for their chemopreventive and anticancer properties. Free Radic Biol Med. 2004;37(3):287-303.

8. Lopez-Lazaro M. Distribution and biological activities of the flavonoid luteolin. Mini Rev Med Chem. 2009;9(1):31-59.

9. Manach C, Scalbert A, Morand C, Remesy C, Jimenez L. Polyphenols: food sources and bioavailability. Am J Clin Nut. 2004;79:727-47.

10. Mekenyan OG, Dimitrov SD, Pavlov TS, Veith GD. A systematic approach to simulating metabolism in computational toxicology. I. The TIMES heuristic modeling framework. Curr Pharm Des. 2004;10(11):1273-93.

11. Middleton E, Kandaswami C. The impact of plant flavonoids on mammalian biology: implications for immunity, inflammation and cancer. In: The flavonoids: advances in research since 1986. Harborne JB, ed. London: Chapman \& Hall; 1994. p. 619-6522.

12. Miller JA. The metabolism of xenobiotics to reactive electrophiles in chemical carcinogenesis and mutagenesis: a collaboration with Elizabeth Cavert Miller and our associates. Drug Metab Rev. 1998;30:645-74.

13. Mitchell JR, Jollow DJ, Potter WZ, Gillette JR, Brodie BB. Acetaminophen-induced hepatic necrosis. IV. Protective role of glutathione. J Pharmacol Exp Ther. 1973;187:211-7.

14. Mitra I, Saha A, Roy K. Chemometric QSAR Modeling and In Silico Design of Antioxidant NO Donor Phenols. Sci Pharm. 2011;79(1):31-57.

15. OECD(Q)SARsApplicationToolbox. Available from: http://www.oecd.org/document/23/0,3343, en_2649_34379_33957015_1_1_1_1,00.html

16. Pearson RG, Songstad J. Application of the principle of hard and soft acids and bases to organic chemistry. J Amer Chem Soc. 1967;89:1827-36.

17. Prescott LF. Hepatotoxicity of mild analgesics. Br J Clin Pharmac. 1980;10:373-9.

18. Rasmussen SE, Frederiksen H, Strunze Krogholm K, Poulsen L. Dietary proanthocyanidins: occurrence, dietary intake, bioavailability, and protection against cardiovascular disease. $\mathrm{Mol}$ Nutr Food Res. 2005;49:159-74.

19. Tepe B, Sokmen M, Akpulat HA, Sokmen A. Screening of the antioxidant potentials of six Salvia species from Turkey. Food Chem. 2006;95(2):200-4.

20. Yoon BH, Jung JW, Lee JJ, Cho YW, Jang CG, Jin $\mathrm{C}$, et al. Anxiolytic-like effects of sinapic acid in mice. Life Sci. 2007;81(3):234-40.

21. Yu MC, Chen JH, Lai CY, Han CY, Ko WC. Luteolin, a non-selective competitive inhibitor of phosphodiesterases 1-5, displaced [3H]-rolipram from high-affinity rolipram binding sites and reversed xylazine/ketamine-induced anesthesia. Eur J Pharmacol. 2010;627:269-75. 